\title{
Comparison of the acute-phase response after laparoscopic versus open aortobifemoral bypass surgery: a substudy of a randomized controlled trial [Erratum]
}

Krog AH, Sahba M, Pettersen EM, et al. Vasc Health Risk

Manag. 2016;12:371-378.

On page 371, author list, the author "Syed SS Kazmi" should have read "Syed SH Kazmi".

Vascular Health and Risk Management is an international, peerreviewed journal of therapeutics and risk management, focusing on concise rapid reporting of clinical studies on the processes involved in the maintenance of vascular health; the monitoring, prevention and treatment of vascular disease and its sequelae; and the involvement of metabolic disorders, particularly diabetes. This journal is indexed on PubMed Central and MedLine. The manuscript management system is completely online and includes a very quick and fair peer-review system, which is all easy to use. Visit http://www.dovepress.com/ testimonials.php to read real quotes from published authors. 